\title{
Quality traits and modeling of coagulation, curd firming, and syneresis of sheep milk of Alpine breeds fed diets supplemented with rumen-protected conjugated fatty acid
}

\author{
G. Bittante, ${ }^{*}$ E. Pellattiero, ${ }^{*}$ F. Malchiodi, ${ }^{*}$ C. Cipolat-Gotet, ${ }^{*}$ M. Pazzola, $†$ G. M. Vacca, $†$ S. Schiavon, ${ }^{*}$ \\ and A. Cecchinato*1 \\ *Department of Agronomy, Food, Natural Resources, Animals and Environment, University of Padova, Viale dell'Università 16, 35020 Legnaro, \\ Italy \\ †Department of Veterinary Medicine, University of Sassari, Via Vienna 2, 07100 Sassari, Italy
}

\begin{abstract}
The aim of this study was to test the modeling of curd-firming (CF) measures and to compare the sheep milk of 3 Alpine breeds supplemented with or without rumen-protected conjugated linoleic acid (rpCLA). Twenty-four ewes of the Brogna, Foza, and Lamon breeds were allotted to 6 pens (2 pens/breed) and fed a diet composed of corn grain, corn silage, dried sugar beet pulp, soybean meal, wheat bran, wheat straw, and a vitamin-mineral mixture. The rpCLA supplement (12 $\mathrm{g} / \mathrm{d}$ per ewe plus $4 \mathrm{~g} / \mathrm{d}$ for each lamb older than 30 d) was mixed into the diet of 1 pen per sheep breed (3 pens/treatment) to provide an average of 0.945 and $0.915 \mathrm{~g} / \mathrm{d}$ per ewe of the cis-9,trans-11 C18:2 and trans-10,cis-12 C18:2 conjugated linoleic acid isomers, respectively. The trial started at $38 \pm 23 \mathrm{~d}$ after parturition, and individual morning milk samples were collected on d 16, 23, 37, 44, and 59 of the trial. Milk samples were analyzed for composition, and duplicate samples were assessed for milk coagulation properties (MCP). A total of $180 \mathrm{CF}$ measures for each sample (1 every $15 \mathrm{~s}$ ) were recorded. Model parameters were the rennet coagulation time, the asymptotic potential $\mathrm{CF}$, the $\mathrm{CF}$ instant rate constant, the syneresis instant rate constant, the maximum $\mathrm{CF}$ achieved within $45 \mathrm{~min}$ $\left(\mathrm{CF}_{\max }\right)$, and the time at achievement of $\mathrm{CF}_{\max }$. The data were analyzed using a hierarchical model that considered the fixed effects of breed, diet, lamb birth, and initial days in milk, which were tested on individual ewe (random) variance; the fixed effect of sampling day, which was tested on the within-ewe sample (random) variance; and the fixed effect of instrument or cuvette position (only for MCP), which was tested on the residual (replicates within samples) variance. The local Alpine sheep breeds displayed similar milk composi-
\end{abstract}

Received August 7, 2013.

Accepted March 22, 2014

${ }^{1}$ Corresponding author: alessio.cecchinato@unipd.it tions, traditional MCP, and $\mathrm{CF}$ modeling parameters. Supplementation with rpCLA triggered changes in milk composition and worsened MCP (e.g., delayed rennet coagulation time, slower CF instant rate constant, and a doubling of syneresis instant rate constant), but did not influence potential CF. Overall, our results indicate that rpCLA supplementation reduced the actual maximum $\mathrm{CF}\left(\mathrm{CF}_{\max }\right)$ but did not modify the interval between rennet addition and $\mathrm{CF}_{\max }$ or time to $\mathrm{CF}_{\max }$. Key words: ovine milk, milk coagulation property, conjugated fatty acid, curd-firming modeling

\section{INTRODUCTION}

For decades, bovine milk coagulation properties (MCP) have been evaluated using mechanical lactodynamographs (Bittante et al., 2012). Three singlepoint parameters are defined: the rennet coagulation time (RCT, min), which is the interval from the addition of the enzyme to the gelation of the milk; the curd-firming $(\mathbf{C F})$ rate $\left(\mathbf{k}_{\mathbf{2 0}}, \mathrm{min}\right)$, or the time from gelation to a $\mathrm{CF}$ of $20 \mathrm{~mm}$; and the $\mathrm{CF}$ measured 30 min after rennet addition $\left(\mathbf{a}_{\mathbf{3 0}}, \mathrm{mm}\right)$. Combinations of these parameters are used to categorize milk samples for their cheese-making properties. Computerized lactodynamographs can record continuous repeated measurements of CF. Bittante (2011b) and Bittante et al. (2013b) proposed a model that fully represents the temporal evolution of $\mathrm{CF}$ on the basis of rennet $\mathrm{RCT}$, the asymptotical potential $\mathrm{CF}$ at infinite time $\left(\mathbf{C F}_{\mathbf{P}}\right.$, $\mathrm{mm})$, the curd-firming instant rate constant $\left(\mathbf{k}_{\mathbf{C F}}\right)$ from $\mathrm{RCT}$ to infinite time, and the syneresis instant rate constant $\left(\mathbf{k}_{\mathbf{S R}}\right)$. Although MCP have not been widely studied among small ruminants, partial studies in this field have been made on sheep (Pellegrini et al., 1997; Jaramillo et al., 2008; Pazzola et al., 2013) and goats (Park et al., 2007; Pazzola et al., 2011, 2012). Notably, the traditional MCP procedure is sometimes considered inadequate for evaluating the milk of these animals (Bittante et al., 2012). Compared with bovine 
milk, the milk-coagulation process of small ruminants is typically much faster and of greater magnitude; thus, $\mathrm{a}_{30}$ often measures $\mathrm{CF}$ after the maximum value has been reached, and $\mathrm{k}_{20}$ measures only a limited tract of the steep increase in CF (Bittante et al., 2012). Thus, the use of the model proposed by Bittante (2011b) and Bittante et al. (2013b) could provide new insights into the coagulation properties of ewe milk, and permit us to evaluate whether these properties can be influenced by breed or different diets and feed additives.

Conjugated linoleic acid has gained attention in recent years for its beneficial effects on human health (Dilzer and Park, 2012). Although these effects have largely been studied in animal models and in vitro (McCrorie et al., 2011), further research is needed (Gebauer et al., 2011). The main source of natural CLA for humans is the consumption of food from ruminant species, especially those fed on pasture or diets containing oil seeds (Nuernberg et al., 2005; Scollan et al., 2006; Woods and Fearon, 2009). However, supplementing the animal diets with rumen-protected CLA (rpCLA; produced by the feed industry) is an effective way to increase the CLA content of beef (Gillis et al., 2004; Schiavon et al., 2011) and lamb (Terré et al., 2011) meat. The rpCLA has shown favorable effects on the efficiency of energy and nitrogen utilization in growing young bulls, and appears to exert a limited effect on fat deposition (Schiavon et al., 2010, 2012; Schiavon and Bittante, 2012). In dairy ruminants, however, the most notable effect of rpCLA is its ability to decrease the fat content in milk from cows (Baumgard et al., 2000; Bauman et al., 2008; Glasser et al., 2010), goats (Lock et al., 2008; Shingfield et al., 2009; Ghazal et al., 2012), and sheep (Oliveira et al., 2012; Weerasinghe et al., 2012). However, whereas numerous studies regarding the effects of rpCLA on dairy ruminants exist, little is known about its influence on MCP.

The aims of the current study were to (1) examine the effect of rpCLA supplementation of lactating ewes on their milk composition; (2) model the CF process of sheep milk; (3) compare the effect of 3 different sheep breeds on milk quality and MCP; and (4) study the effects of rpCLA supplementation on the composition and MCP of sheep milk.

\section{MATERIALS AND METHODS}

\section{Animals}

The present study was carried out at the Lucio Toniolo Experimental Farm of the University of Padova (Legnaro, Italy), using a flock of sheep representing endangered Alpine breeds native to the Veneto Region (northeast Italy). Animals were treated following the
Guideline for the Care and Use of Agricultural Animals in Agricultural Research and Teaching (FASS, 1988). The study involved 24 ewes, of them, 10, 9, and 5 ewes belonged to the Brogna, Foza, and Lamon breeds, respectively. The 24 ewes were allotted to 6 pens of $3 \times$ $6 \mathrm{~m}$ (2 for each breed) with their 31 suckling lambs $(15,10$, and 6 for the Brogna, Foza, and Lamon breeds, respectively). At the start of the trial, the ewes were $38 \pm 23$ DIM and weighed $61 \pm 13 \mathrm{~kg}$. The trial lasted $63 \mathrm{~d}$. Ewes and lambs were individually weighed each week. Animals were monitored daily by a technician and health status was controlled 3 times per week by a veterinarian following the experimental protocol for animal care.

\section{Feeds and Feeding}

The basal diet was composed of corn grain, corn silage, dried sugar beet pulp, soybean meal, wheat bran, wheat straw, and a vitamin-mineral mixture (Table 1). Dietary ingredients were mixed and fed as a TMR, offered ad libitum, and prepared daily using a mixerwagon equipped with a computer-assisted weighing scale that was calibrated monthly. Three pens, 1 for each breed, with 5, 4, and 3 Brogna, Foza, and Lamon ewes, respectively, received the basal diet; the remaining 3 pens (with 5, 5, and 2 Brogna, Foza, and Lamon ewes, respectively, 12 in total) received the same basal diet top dressed and then mixed with TMR, with an rpCLA product (SILA, Noale, Italy) equal to $12 \mathrm{~g} / \mathrm{d}$ per ewe plus $4 \mathrm{~g} / \mathrm{d}$ per lamb aged $30 \mathrm{~d}$ or more. This rpCLA dose was established to provide averages of 0.945 and $0.915 \mathrm{~g} / \mathrm{d}$ per ewe for the cis-9,trans-11 C18:2 and trans-10,cis-12 C18:2 CLA isomers, respectively. The composition of the commercial rpCLA used was previously reported by Schiavon et al. (2010). The amount of each feed ingredient loaded into the mixer-wagon and the weight of the mixture uploaded in the manger of each pen were recorded daily. The orts remaining in the mangers were weighed weekly by pen. The average DMI was computed on a pen basis.

Samples of each feed ingredient were analyzed for their proximate compositions (AOAC International, 2000) and their NDF and ADF contents (Van Soest et al., 1991). The ME of the basal ration was computed from the actual ration ingredient composition and tabular values of each feed ingredient (NRC, 2007).

\section{Milk Sampling and Analyses}

The ewes were separated from their lambs for at least $2 \mathrm{~h}$ and then hand milked on d 16, 23, 37, 44, and 59. After collection, milk samples (without preservative) were immediately divided into subsamples A $(35 \mathrm{~mL})$ 
Table 1. Ingredients, chemical composition, DM, and ME of a TMR and its ingredients

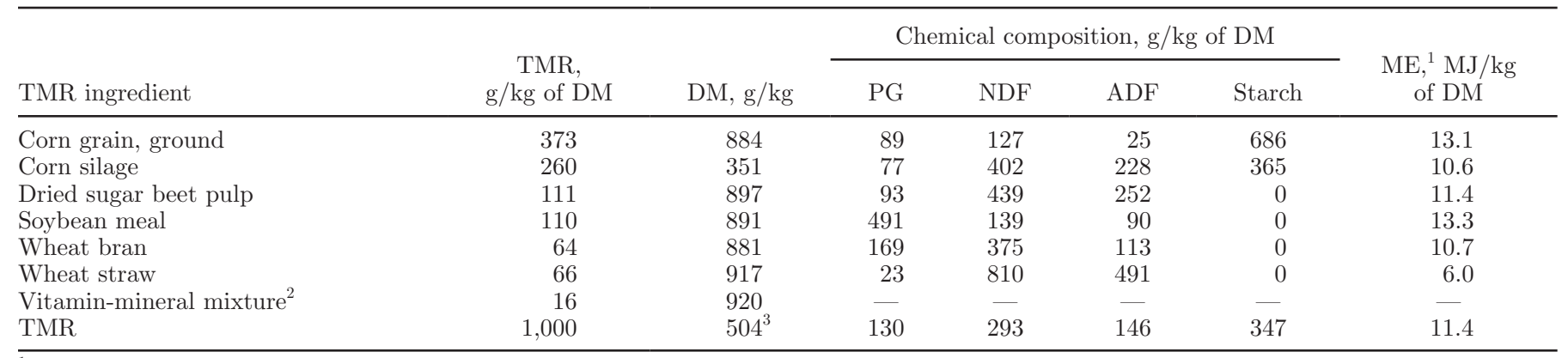

${ }^{1}$ Values taken from NRC (2007)

${ }^{2}$ Content per kilogram of DM: $12.4 \mathrm{~g}$ of Ca, $1.7 \mathrm{~g}$ of P, $2.5 \mathrm{~g}$ of Na, $100 \mathrm{mg}$ of Cu, $300 \mathrm{mg}$ of Zn, $1.0 \mathrm{mg}$ of Co, $3 \mathrm{mg}$ of I, $1 \mathrm{mg}$ of Se, $200 \mathrm{mg}$ of $\mathrm{Mn}, 22,000 \mathrm{IU}$ of vitamin $\mathrm{A}, 83 \mathrm{IU}$ of vitamin $\mathrm{E}$, and 2,750 IU of vitamin $\mathrm{D}_{3}$.

${ }^{3}$ Including water added to the mixer wagon to increase moisture of the TMR.

and $\mathrm{B}(20 \mathrm{~mL})$, stored in portable refrigerators $\left(4^{\circ} \mathrm{C}\right)$, and transported to the cheese-making laboratory at the Department of Agronomy, Food, Natural Resources, Animals and Environment of the University of Padova for analyses. All samples were processed within $5 \mathrm{~h}$ after collection.

For each ewe, milk subsample A was analyzed for fat, protein, lactose, TS, and nonfat solids contents using a MilkoScan FT2 (Foss, Hillerød, Denmark). In addition, SCC were performed using a Fossomatic FC counter (Foss). Each SCC was converted to the SCS by means of logarithmic transformation as SCS $=\left(\log _{2} \mathrm{SCC} \times\right.$ $\left.100,000^{-1}\right)-3$. The energy of milk was calculated using the values proposed by the NRC (2007) and converted to kilojoules per gram (fat $=38.89 \mathrm{~kJ} / \mathrm{g}$; protein $=$ $23.90 \mathrm{~kJ} / \mathrm{g}$; lactose $=16.53 \mathrm{~kJ} / \mathrm{g})$.

\section{Analysis of MCP}

The B subsamples were assessed for MCP using 2 mechanical lactodynamographs (Formagraph, Foss). All experimental conditions (milk temperature, rennet concentration, and rennet type) were applied as described in detail by Cipolat-Gotet et al. (2012). In brief, a rack containing 10 cuvettes (1 rack per instrument) was prepared. Two milk subsamples $(10 \mathrm{~mL})$ for each ewe were randomly allotted to the 2 racks, heated at $35^{\circ} \mathrm{C}$, and mixed with $200 \mu \mathrm{L}$ of rennet solution (Hansen Standard 215 with $80 \pm 5 \%$ chymosin and 20 $\pm 5 \%$ pepsin; Pacovis Amrein AG, Bern, Switzerland) diluted to $1.2 \%$ (wt/vol) in distilled water [to yield 0.051 international milk clotting units $(\mathbf{I M C U}) / \mathrm{mL}$ ]. The instruments recorded the width (in millimeters) of the oscillatory graph during the test every $15 \mathrm{~s}$. The observation period lasted for $45 \mathrm{~min}$ after rennet addition. Traditional MCP (RCT, $\mathrm{k}_{20}$, and $\mathrm{a}_{30}$ ) were provided directly by the instrument. Recording was prolonged to
45 min after enzyme addition to achieve an additional measure of $\mathrm{CF}\left(\mathbf{a}_{\mathbf{4 5}}, \mathrm{mm}\right)$. Relatively few samples (8 of 206 samples) failed to coagulate within the 45-min duration of the test.

\section{Modeling Curd Firmness and Syneresis}

As CF was measured every $15 \mathrm{~s}$ for $45 \mathrm{~min}$, a total of $180 \mathrm{CF}$ values were recorded for each sample. The comparison of the much shorter RCT values of ovine milk to those of bovine milk, and the prolongation of recording to $45 \mathrm{~min}$ enabled the use of the 4-parameter model described by Bittante et al. (2013b):

$$
\mathrm{CF}_{t}=\mathrm{CF}_{\mathrm{P}} \times\left[1-e^{-\mathrm{k}_{\mathrm{CF}} \times(t-\mathrm{RCT})}\right] \times e^{-\mathrm{k}_{\mathrm{SR}} \times(t-\mathrm{RCT})},
$$

where $\mathrm{CF}_{t}$ is the curd firmness at time $t(\mathrm{~mm}) ; \mathrm{CF}_{\mathrm{P}}$ is the asymptotic potential maximum value of curd firmness $(\mathrm{mm}) ; \mathrm{k}_{\mathrm{CF}}$ is the curd-firming instant rate constant $(\% / \mathrm{min}) ; \mathrm{k}_{\mathrm{SR}}$ is the curd syneresis instant rate constant $(\% / \mathrm{min})$; and $\mathrm{RCT}$ is the rennet coagulation time (min).

This model uses all available information to estimate the 4 parameters; therefore (unlike the traditional MCP), these are not single-point measurements. The $\mathrm{CF}_{\mathrm{P}}$ parameter is conceptually independent from test duration and (unlike $\mathrm{a}_{30}$ ) is not intrinsically dependent on RCT. The parameter $\mathrm{k}_{\mathrm{CF}}$ is assumed to increase $\mathrm{CF}$ toward the $\mathrm{CF}_{\mathrm{P}}$ asymptotic value, whereas $\mathrm{k}_{\mathrm{SR}}$ is assumed to decrease CF toward a null asymptotic value. In the initial phase of the test, the first rate constant prevails over the second, so $\mathrm{CF}_{t}$ increases to a point in time $\left(\boldsymbol{t}_{\max }\right)$ at which the effects of the 2 parameters are equal but opposite in sign and $\mathrm{CF}_{t}$ attains its maximum level $\left(\mathbf{C F}_{\text {max }}\right)$. Thereafter, $\mathrm{CF}_{t}$ begins to decrease, tending toward a null value because of the effect of curd 
syneresis and the corresponding expulsion of whey. The RCT parameter is still a traditional measure, but it is now estimated using all available data.

\section{Statistical Analyses}

The $\mathrm{CF}_{t}$ observations available for each sample were fitted with curvilinear regressions using the nonlinear procedure (PROC NLIN) of SAS (Version 8.2, SAS Institute Inc., Cary, NC). The parameters of each individual equation were estimated employing the Marquardt iterative method (350 iterations and a $10^{-5}$ level of convergence). In some late-coagulating samples (6 of 206 samples), the data did not converge. Samples in which the $\mathrm{CF}_{\mathrm{P}}$ exceeded the replicate (3 cases) or the mean (3 cases) by 3 SD were considered outliers and excluded from our analysis of all equation parameters. No data editing was performed for the other parameters.

The data regarding milk analyses, traditional MCP, and $\mathrm{CF}$ modeling were analyzed using a linear mixed model employing the MIXED procedure of SAS. The statistical model used to analyze the traditional MCP and the parameters of the $\mathrm{CF}_{t}$ model included the fixed effects of breed (Brogna, Foza, and Lamon), dietary treatment (control vs. rpCLA addition), number of lambs suckling (single or twin lambing), a linear covariate of DIM at the start of the trial, sampling day (16, $23,37,44$, and $59 \mathrm{~d}$ from the start of the trial), and the cuvette location within the 2 instruments (18 levels). The random effects included in the model were the individual animal (24 ewes, $16 \mathrm{df}$ ), the milk samples within each ewe (77 df), and the replicates within each milk sample (residual, $70 \mathrm{df}$ ). The significances of breed, diet, number of lambs, and DIM were tested on the error line of animal variance; sampling day was tested on the error line of milk sample variance within animals; and cuvette location within instruments was tested on the residual variance. For milk quality traits, the 2 replicates were averaged and the within-ewe samples were assumed to coincide with the residual variance.

In the case of each ewe's live weight (1 observation per animal, data not shown), the model was simplified because it did not include the effects of sampling day or the cuvette location within the instrument, and the only random effect included (residual) coincided with the animal. In the case of DMI (1 observation per pen, data not shown), the model included only the effect of diet and breed, and the residual coincided with their interaction.

\section{RESULTS}

Brogna ewes presented a lower BW compared with the Foza and Lamon ewes (51.8 vs. 71.1 and $71.2 \mathrm{~kg}$, respectively; $P<0.01$ ), and Brogna and Foza ewes consumed less DM than Lamon ewes (2.45 and 2.50 vs. $3.00 \mathrm{~kg}$ of DM/d, respectively; $P<0.05)$. Supplementation with rpCLA did not influence the DMI of ewes and lambs (expressed per unit of ewe present; 2.63 vs. 2.67 $\mathrm{kg}$ of $\mathrm{DM} / \mathrm{d}$, respectively, for control and supplemented diets), or influence the BW and average body gains of ewes and lambs, regardless of breed.

However, rpCLA supplementation did affect the milk composition, reducing the protein and nonfat solids contents as it increased the SCS (Table 2). All of the other factors included in the model, with the exception of sampling day (which was significant for almost all traits), had limited effects; the Lamon breed yielded milk with a lower nonfat solids content compared with Foza ewes, and ewes that had lambed twins or had longer intervals of DIM at the beginning of the trial produced milk with greater protein and nonfat solids contents.

The only breed effect observed among the traditional traits used to depict MCP was a lower $\mathrm{a}_{45}$ for Lamon versus Foza sheep (Table 3). The MCP were significantly worse when rpCLA was added to the basal diet, as RCT was delayed, CF was slowed, and $\mathrm{a}_{30}$ and $\mathrm{a}_{45}$ were lower. Twin lambing had positive effects on both measures of CF. Days in milk at the beginning of the trial did not affect any MCP, whereas sampling day and cuvette location influenced all traits except RCT.

For the $\mathrm{CF}_{t}$ model parameters, milk from Lamon ewes was characterized by slower curd firming and faster syneresis compared with the Foza breed (Table 4). Similar to the traditional MCP, the parameters obtained from $\mathrm{CF}_{t}$ modeling showed that rpCLA supplementation had negative effects on the parameters of coagulation and curd firming, except for the asymptotic CF value and the interval between the addition of the enzyme and the moment of maximum CF. In milk sampled from rpCLA-supplemented ewes, the expulsion of whey from the curd (i.e., the syneresis rate) was much faster and the number of samples showing no detectable syneresis within 45 min from rennet addition was halved.

The birth type affected the CF modeling, as samples from ewes with twin lambs showed more rapid decreases of $\mathrm{CF}$ after reaching the maximum (i.e., more rapid syneresis). The sampling day and instrument or cuvette location affected all modeling parameters except for RCT (both factors) and $\mathrm{CF}_{\mathrm{P}}$ (sampling day).

\section{DISCUSSION}

\section{Traditional Coagulation Properties of Sheep Milk}

The enzymatic coagulation of milk, the firming of curd, and the subsequent expulsion of whey (syneresis) 
Table 2. Effect of breed, rumen-protected conjugated linoleic acid (rpCLA) supplementation, birth type, DIM at first sampling, and date of sampling on quality traits of ewe milk

\begin{tabular}{|c|c|c|c|c|c|c|c|}
\hline Item & Fat, $\%$ & Protein, $\%$ & Lactose, $\%$ & TS, $\%$ & $\begin{array}{c}\text { Nonfat } \\
\text { solids, \% }\end{array}$ & $\begin{array}{l}\text { Energy, } \\
\text { MJ/kg }\end{array}$ & SCS, U \\
\hline \multicolumn{8}{|l|}{ Breed } \\
\hline Lamon (La) & 6.69 & 5.51 & 5.08 & 17.7 & 11.7 & 4.75 & 5.96 \\
\hline \multicolumn{8}{|l|}{ Contrasts, $P$-value } \\
\hline Br vs. $($ Fo + La $) / 2$ & 0.52 & 0.34 & 0.40 & 0.45 & 0.47 & 0.50 & 0.74 \\
\hline Control & 6.56 & 5.82 & 5.12 & 18.0 & 12.1 & 4.79 & 4.37 \\
\hline rpCLA addition & 5.94 & 5.48 & 5.16 & 17.1 & 11.7 & 4.47 & 5.76 \\
\hline$P$-value & 0.41 & 0.02 & 0.77 & 0.21 & 0.007 & 0.29 & 0.06 \\
\hline \multicolumn{8}{|l|}{ Birth type } \\
\hline Single & 6.25 & 5.46 & 5.12 & 17.3 & 11.7 & 4.58 & 5.22 \\
\hline Twin & 6.24 & 5.85 & 5.16 & 17.7 & 12.1 & 4.68 & 4.90 \\
\hline$P$-value & 0.99 & 0.01 & 0.79 & 0.56 & 0.01 & 0.77 & 0.69 \\
\hline Ewe $\mathrm{RMS}^{1}$ & 1.88 & 0.05 & 0.06 & 1.53 & 0.06 & 0.29 & 1.89 \\
\hline Sampling day, $P$-value & $<0.001$ & 0.08 & 0.01 & $<0.001$ & 0.02 & $<0.001$ & 0.13 \\
\hline $\mathrm{RMSE}^{2}$ & 2.00 & 0.07 & 0.04 & 1.44 & 0.08 & 0.28 & 0.84 \\
\hline
\end{tabular}

${ }^{1}$ Ewe RMS = ewe root mean square.

${ }^{2} \mathrm{RMSE}=$ root mean square error.

Table 3. Effect of breed, rumen-protected conjugated linoleic acid (rpCLA) supplementation, birth type, DIM at first sampling, date of sampling, and instrument or cuvette position on traditional milk coagulation properties of ewe's milk ${ }^{1}$

\begin{tabular}{|c|c|c|c|c|}
\hline Item & $\mathrm{RCT}$, min & $\mathrm{k}_{20}, \min$ & $\mathrm{a}_{30}, \mathrm{~mm}$ & $\mathrm{a}_{45}, \mathrm{~mm}$ \\
\hline \multicolumn{5}{|l|}{ Breed } \\
\hline Brogna (Br) & 8.68 & 1.62 & 59.3 & 54.8 \\
\hline Foza $(\mathrm{Fo})$ & 7.18 & 1.57 & 58.7 & 55.2 \\
\hline Lamon (La) & 8.05 & 1.67 & 54.6 & 47.8 \\
\hline \multicolumn{5}{|l|}{ Contrasts, $P$-value } \\
\hline Br vs. $(\mathrm{Fo}+\mathrm{La}) / 2$ & 0.36 & 0.99 & 0.17 & 0.16 \\
\hline Fo vs. La & 0.51 & 0.41 & 0.07 & 0.01 \\
\hline \multicolumn{5}{|l|}{ Diets } \\
\hline Control & 6.50 & 1.46 & 60.6 & 56.9 \\
\hline rpCLA addition & 9.44 & 1.78 & 54.5 & 48.3 \\
\hline$P$-value & 0.01 & 0.004 & 0.003 & $<0.001$ \\
\hline \multicolumn{5}{|l|}{ Lambs born } \\
\hline Single & 7.66 & 1.66 & 55.2 & 50.0 \\
\hline Twin & 8.29 & 1.58 & 59.9 & 55.2 \\
\hline$P$-value & 0.59 & 0.44 & 0.02 & 0.03 \\
\hline \multicolumn{5}{|l|}{ DIM } \\
\hline Regression coefficient & -0.028 & -0.004 & -0.006 & -0.113 \\
\hline$P$-value & 0.38 & 0.17 & 0.91 & 0.08 \\
\hline Ewe RMS ${ }^{2}$ & 1.78 & 0.16 & 2.10 & 2.14 \\
\hline Sampling day, $P$-value & 0.56 & 0.02 & $<0.001$ & 0.002 \\
\hline Sample RMS ${ }^{3}$ & 2.46 & 0.20 & $\mathrm{NE}^{4}$ & $\mathrm{NE}$ \\
\hline Instrument/position, $P$-value & 0.11 & $<0.001$ & $<0.001$ & $<0.001$ \\
\hline RMSE $^{5}$ & 1.08 & 0.16 & 7.86 & 10.46 \\
\hline
\end{tabular}

${ }^{1} \mathrm{RCT}=$ rennet coagulation time; $\mathrm{k}_{20}$ time interval between coagulation and attainment of a curd firmness of $20 \mathrm{~mm} ; \mathrm{a}_{30}\left(\mathrm{a}_{45}\right)=$ curd firmness after 30 (45) min from rennet addition.

${ }^{2}$ Ewe RMS $=$ ewe root mean square.

${ }^{3}$ Sample RMS $=$ sample root mean square.

${ }^{4} \mathrm{NE}=$ not estimable.

${ }^{5} \mathrm{RMSE}=$ root mean square error. 
Table 4. Effect of breed, rumen-protected conjugated linoleic acid (rpCLA) supplementation, birth type, DIM at first sampling, date of sampling, and instrument or cuvette position on modeling of coagulation, curd firming, and syneresis of ewe milk ${ }^{1}$

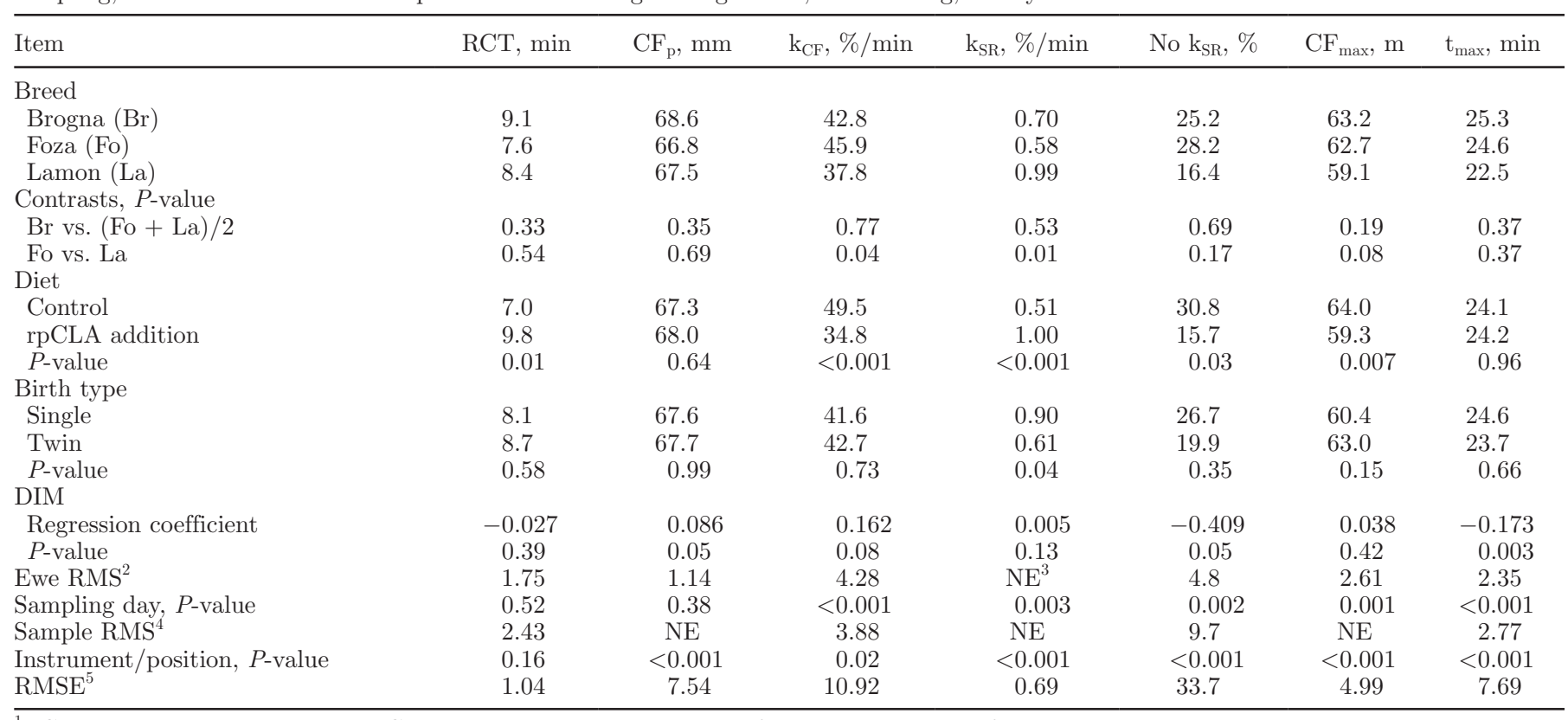

${ }^{1} \mathrm{RCT}=$ rennet coagulation time; $\mathrm{CF}_{\mathrm{P}}=$ asymptotic potential curd firmness; $\mathrm{k}_{\mathrm{CF}}=$ curd firming instant rate constant; $\mathrm{k}_{\mathrm{SR}}=$ syneresis instant rate constant; No $\mathrm{k}_{\mathrm{SR}}=$ incidence of milk samples with not estimable $\mathrm{k}_{\mathrm{SR}} ; \mathrm{CF}_{\max }=$ maximum curd firmness achieved within 45 min; $\mathrm{t}_{\max }=$ time at achievement of $\mathrm{CF}_{\max }$.

${ }^{2}$ Ewe RMS = ewe root mean square.

${ }^{3} \mathrm{NE}=$ not estimable.

${ }^{4}$ Sample RMS $=$ sample root mean square

${ }^{5} \mathrm{RMSE}=$ root means square error.

are the key processes in cheese-making, and thus affect cheese yield and quality (Bittante et al., 2013a; CípolatGotet et al., 2013). However, the mechanical and optical near infrared (NIR) lactodynamographs (Cipolat-Gotet et al., 2012) that are generally used to measure these traits are nonautomated and time-consuming. In the bovine dairy industry, the Fourier-transform infrared spectrum of milk, which is heritable (Bittante and Cecchinato, 2013), was recently introduced as a method for predicting the parameters traditionally measured by lactodynamographs. The Fourier-transform infrared prediction is very rapid and inexpensive, does not need enzymes or mechanical tools, and does not require milk coagulation to occur. Such indirect predictions may also prove useful for breeding programs (Cecchinato et al., 2009). To our knowledge, however, these techniques have not previously been tested on milk from small ruminant species and more research is needed on this topic.

The data obtained in the present study confirmed that large differences exist between ovine and bovine $\mathrm{MCP}$, as reported in Table 3. The average RCT measured from control ewes $(6.5 \mathrm{~min})$ was much shorter than that commonly found in bovine species (10 to 20 min), as reviewed by Bittante et al. (2012). The average $\mathrm{k}_{20}$ revealed that a much steeper increase in the $\mathrm{CF}$ of ovine milk (1.5 min) compared with bovine milk (5 to $10 \mathrm{~min})$. The average $\mathrm{CF}$ after $30 \mathrm{~min}$ was also greater for sheep milk (61 mm) than cow milk (25 to $42 \mathrm{~mm}$ ). Notably, the rennet concentration used in the present study $(0.051 \mathrm{IMCU} / \mathrm{mL})$ was smaller than those in all but one of the papers on bovine MCP reviewed by Bittante et al. (2012; 0.061 to $0.150 \mathrm{IMCU} / \mathrm{mL}$ ), and this disparity widens if the amount of rennet is expressed per unit protein instead of per unit of milk. Moreover, the milk of cows and ewes reacts differently to acidification, temperature changes, calcium addition, and variation in rennet concentration (Bencini, 2002).

\section{Modeling the Coagulation, CF, and Syneresis of Sheep Milk}

Two other shortcomings of the traditional MCP parameters are the increasing percentage of bovine milk samples that do not coagulate within the commonly used time interval of $30 \mathrm{~min}$ from rennet addition (Ikonen et al., 1999; Cecchinato, 2013) and the increasing proportion of milk samples that do not allow computation of the $\mathrm{k}_{20}$ trait. These increases reflect the worldwide spread of the Holstein breed, which are 
known for having inferior MCP compared with breeds of Alpine origins (Cecchinato et al., 2011). A similar problem has been noted in small ruminants (Pazzola et al., 2012, 2013). The traditional MCP analysis uses only 3 data points, whereas computerized rennet meters (lactodynamographs) use continuous repeated measurements. Bittante (2011b) modeled a data set recorded from individual bovine milk samples using computerized rennet meters over 30 min (120 records, 1 every 15 $\mathrm{s}$, in the case of Formagraph lactodynamographs) and proposed to use the obtained $\mathrm{CF}$ curve to estimate the $\mathrm{RCT}$, the asymptotical potential $\mathrm{CF}$ at infinite time $\left(\mathrm{CF}_{\mathrm{P}}\right)$, and the $\mathrm{CF}$ instant rate constant $\left(\mathrm{k}_{\mathrm{CF}}\right)$ from RCT to infinite time. Later, Bittante et al. (2013b) expanded the $\mathrm{CF}$ model to account for the decrease in $\mathrm{CF}$ often recorded after (though sometimes before) 30 min from rennet addition, using a forth parameter called the syneresis rate constant $\left(\mathrm{k}_{\mathrm{SR}}\right)$.

In the case of sheep milk, the traditional MCP traits are considered even less reliable in depicting the process of CF, largely because the process is much faster and of greater magnitude compared with bovine milk, such that $\mathrm{a}_{30}$ often measures $\mathrm{CF}$ after the maximum value has already been reached and $\mathrm{k}_{20}$ measures only a limited tract of the steep increase in CF (Bittante et al., 2012). The present study showed that the model proposed by Bittante et al. (2013b) overcomes the concerns linked to traditional MCP measures, yielding results that can depict the evolution of $\mathrm{CF}$ over time for sheep milk. In fact, the large majority of individual samples converged, allowing us to estimate the values for all 4 parameters of the model. Compared with the bovine milk studied by Bittante et al. (2013b), the control sheep milk samples analyzed in the present study showed, on average, a much earlier gelation (RCT of 7.0 vs. 19.3 and 20.7 min compared with Brown Swiss and Holstein Friesian cows, respectively), a greater asymptotic potential $\mathrm{CF}\left(\mathrm{CF}_{\mathrm{P}}\right.$ of 67 vs. 54 and 36 $\mathrm{mm}$, respectively), a much steeper increase in $\mathrm{CF}\left(\mathrm{k}_{\mathrm{CF}}\right.$ of 49.5 vs. 12.0 and $13.0 \% / \mathrm{min}$, respectively), and a slower decrease in $\mathrm{CF}$ due to syneresis $\left(\mathrm{k}_{\mathrm{SR}}\right.$ of 0.5 vs. 1.4 and $1.7 \% / \mathrm{min}$, respectively). Regarding this last parameter, $\sim 30 \%$ of milk samples from control ewes did not exhibit any apparent decrease of CF during the 45 min after rennet addition, meaning that the $\mathrm{k}_{\mathrm{SR}}$ could not be estimated and was assumed to be null. If we excluded these samples, the average $\mathrm{k}_{\mathrm{SR}}$ of the remaining samples was $0.6 \% / \mathrm{min}$. In practice, the $\mathrm{CF}$ equation of the samples characterized by nonestimable $\mathrm{k}_{\mathrm{SR}}$ values coincided with the 3-parameter model that was initially proposed by Bittante (2011b) to depict the $\mathrm{CF}$ trends of lactodynamograms generated over a short observation interval (30 min for cow milk). It is prob- able that prolonging the observation interval beyond 45 min would have allowed us to estimate $\mathrm{k}_{\mathrm{SR}}$ for the samples that failed to show any significant decrease within the test period. Bittante et al. (2013b) prolonged their recording interval to $90 \mathrm{~min}$ and observed that almost all of their bovine milk samples presented an inflection, allowing them to compute $\mathrm{k}_{\mathrm{CF}}$ for all samples. In any case, the samples with late CF decreases were characterized by very slow syneresis rate constants.

For each milk sample, knowing the 4 parameters of the $\mathrm{CF}$ curve allowed us to calculate the maximum $\mathrm{CF}$ value $\left(\mathrm{CF}_{\max }\right)$, which reflects the potential $\mathrm{CF}$ attainable and the 2 opposite effects of $\mathrm{CF}$ rate and syneresis rate, and the time interval from rennet addition to the attainment of the maximum $\mathrm{CF}\left(t_{\max }\right)$, which also incorporates the RCT. Compared with the milk of Brown Swiss cows tested by Bittante et al. (2013b), the sheep milk examined in the current study showed a greater $\mathrm{CF}_{\max }$ (64 vs. $35 \mathrm{~mm}$, respectively) and reached $t_{\max }$ earlier (24 vs. $41 \mathrm{~min}$, respectively). The average $t_{\max }$ of the sheep milk samples presented in Table 4 includes samples that failed to show any decrease within $45 \mathrm{~min}$ from rennet addition; for these last samples, $t_{\max }$ was assumed to be $45 \mathrm{~min}$. When these samples were excluded from the analysis, we obtained an average $t_{\max }$ of $15 \mathrm{~min}$. We cannot compare these parameters to others in the literature because the present study is the first to model the output of computerized rennet meters when examining ovine milk.

\section{Comparison Among the Sheep Breeds of the Veneto Alps}

Brogna, Foza, Lamon, and Alpagota are the only autochthonous sheep breeds of the Italian Alps still present in the northern part of the Veneto region (Bittante, 2011a). Brogna sheep, which are reared in the province of Verona, are of medium size (similar to Alpagota) and characterized by red spots on a white coat (Pastore, 2002; Pellattiero et al., 2011). Of the 3 breeds studied herein, Brogna is the only breed that was often used (and in some cases is still used today) as a dairy ewe; its milk can be used to produce a local pecorino (Pegorin) cheese. The other 2 local breeds, which are both in danger of extinction, are reared in very low numbers in the provinces of Vicenza (Foza) and Belluno (Lamon). Both are large breeds with high growth rates among their lambs; they have long ears and small black spots (especially on the head) against a white coat (Pastore, 2002). These breeds are traditionally reared for meat production (mainly from weaned lambs and castrated yearlings). The Lamon breed has been studied in the past decades (Bittante et al., 1996; Ramanzin et al., 


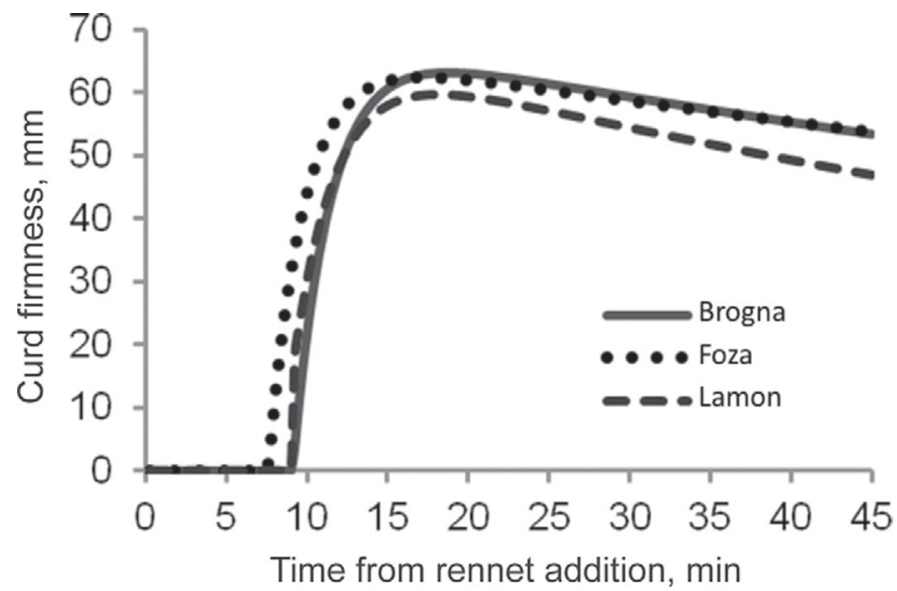

Figure 1. Effect of sheep breed on coagulation, curd firming, and syneresis processes of ewe milk.

1991), but no previous study has examined the quality and coagulation properties of milk from the Veneto sheep breeds.

The contents of fat, protein, and lactose in the Veneto sheep breeds are close to the average values reported by Barłowska et al. (2011) for ovine milk in their literature review on the composition of ruminant milk, and are very good if compared with milk traits recorded for specialized dairy ewes, such as the Sarda sheep (Mura et al., 2012; Vacca et al., 2013). The milk compositions of the 3 local Alpine breeds were very similar, with the sole exception of higher nonfat solids content in Foza milk compared with Lamon milk (Table 2).

The 2 larger breeds also presented some differences in terms of the traditional MCP, as Foza milk samples tended to have greater $\mathrm{a}_{30}(P=0.07)$ and $\mathrm{a}_{45}(P=0.01)$ values. A picture of the difference between the 2 breeds, given in Figure 1, shows that milk from Foza ewes was characterized by a steeper increase $\left(\mathrm{k}_{\mathrm{CF}}\right)$ and a slower decrease $\left(\mathrm{k}_{\mathrm{SR}}\right)$ in $\mathrm{CF}$ compared with the milk of Lamon ewes. The graphical representation of $\mathrm{CF}$ evolution over time provides a much clearer picture of the pattern of coagulation, $\mathrm{CF}$, and syneresis than we would obtain using only the 3 points considered by the traditional $\mathrm{MCP}$ procedure $\left(\mathrm{RCT}, \mathrm{a}_{30}\right.$, and $\mathrm{k}_{20}$ ). From the shapes of the curves, we see that traditional $\mathrm{k}_{20}$ measures only about one-third of the increase of the $\mathrm{CF}_{t}$ curve, that $\mathrm{a}_{30}$ is in the decreasing tract of the curve and not in the increasing one, as for bovine milk, and it is influenced by all the other parameters. Finally, the differences in the milk $\mathrm{CF}_{t}$ curves due to single or twin lambings (Figure 2) were mainly caused by differences in syneresis.

\section{Effect of rpCLA on the Composition of Sheep Milk}

We found that rpCLA supplementation strongly modified milk composition in sheep, even though the ewes received less than $1 \mathrm{~g}$ of each CLA isomer per day. The rpCLA-induced decrease in milk fat content was only nominal $(-0.62$ percentage points; not significant), but it was similar in magnitude to that found in dairy cows that received similar CLA dosages expressed per unit of metabolic weight (Baumgard et al., 2000; Selberg et al., 2004; Castañeda-Gutiérrez et al., 2005). The rpCLA-induced decrease in milk fat observed herein was much lower than that previously observed in sheep $(\sim-2.57$ and -2.26 percentage points; $P<$ 0.001) (Weerasinghe et al., 2012). However, whereas those authors used sheep (breed unspecified) of similar BW and DIM compared with those used in the present study, their sheep were milked twice a day and received a restricted diet (DMI of 1.8 vs. $2.6 \mathrm{~kg} / \mathrm{d}$ in the prior and present studies, respectively) that had a lower dietary energy concentration (ME of 10.9 vs. $11.4 \mathrm{MJ} / \mathrm{kg}$ of $\mathrm{DM}$, respectively) and a greater dietary $\mathrm{CP}$ content (CP of 163 vs. $130 \mathrm{~g} / \mathrm{kg}$ of DM, respectively). In addition, whereas the CLA source was the same, the daily supply in the prior study was about twice that used in the current study. In dairy cows, the effect of rpCLA supplementation on milk fat content was lower in animals fed high-concentrate diets compared with those fed low-concentrate diets. The available energy supply may influence the response of the mammary gland to CLA isomers, particularly trans-10, cis-12 C18:2, as suggested by Glasser et al. (2010). Oliveira et al. (2012) also recorded a large reduction ( -1.76 percentage points) of milk fat content in CLA-supplemented ewes of the Lacaune breed (a specialized dairy sheep breed), but the authors used 10-fold more (not rumen-protected) CLA isomers compared with the current study.

Supplementation with rpCLA decreased the protein and nonfat solids contents of sheep milk $(-0.34$,

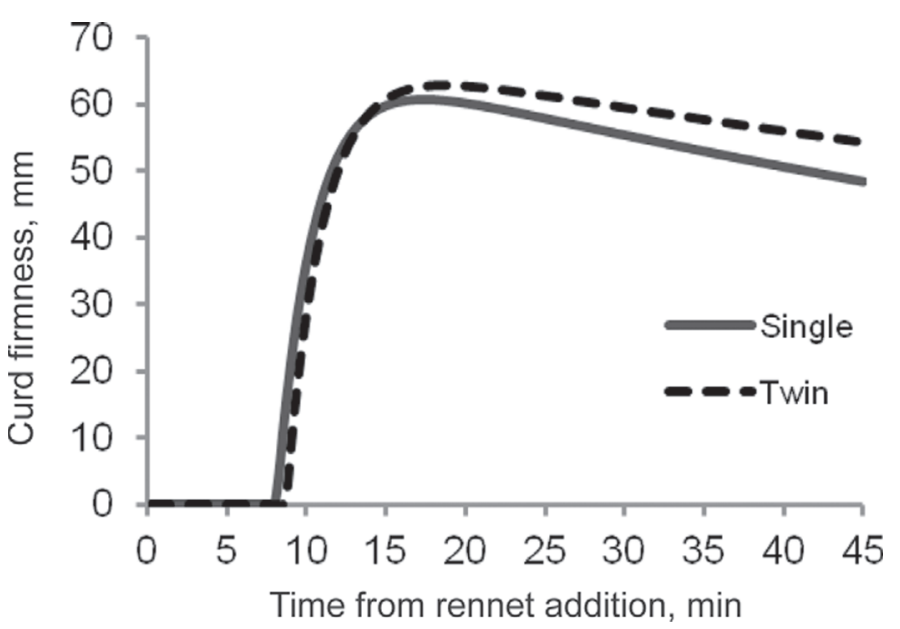

Figure 2. Effect of number of lambs born on coagulation, curd firming, and syneresis processes of ewe milk. 


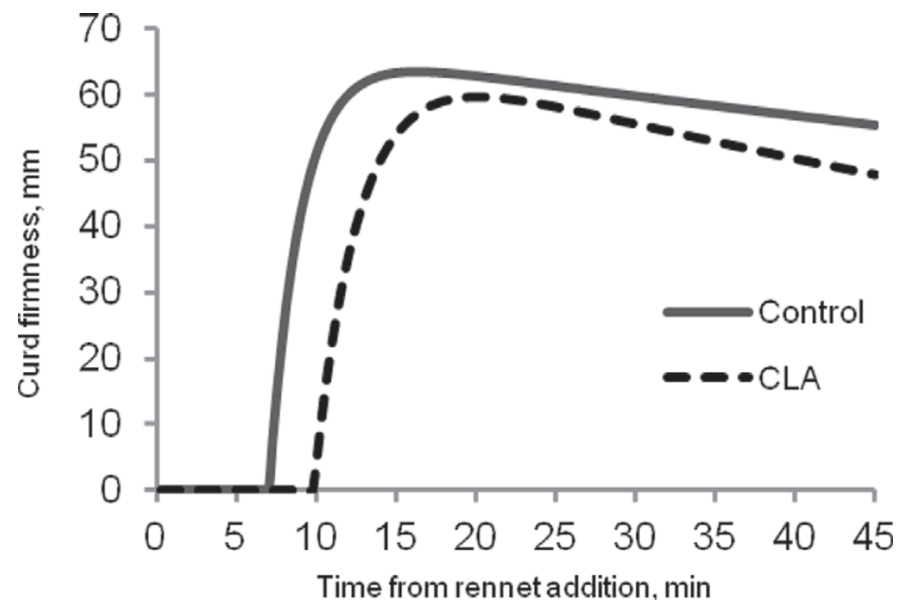

Figure 3. Effect of rumen-protected conjugated linoleic acid supplementation to diet on coagulation, curd firming, and syneresis processes of ewe milk.

-0.40 , and -2.7 percentage points, respectively) compared with the control. Previously cited studies found inconsistent effects of CLA on milk protein content. In sheep, Weerasinghe et al. (2012) found a negative effect, whereas Oliveira et al. (2012) found a positive effect. In cows, the effect of CLA on milk protein content generally appears to be low or null (Maxin et al., 2011; Hötger et al., 2013).

In terms of other possible effects on milk quality, we observed that rpCLA supplementation tended to increase the SCS compared with the control. In bovine milk, the observed changes in milk composition (especially those in protein content) are generally considered negative for MCP because of their well-known phenotypic and genetic correlations (Cecchinato et al., 2011; Bittante et al., 2012).

\section{Effect of rpCLA on Curd Firmness and Syneresis}

In the literature, no information exists regarding the effects of rpCLA administration on coagulation, CF, and syneresis in both bovine and sheep milk. In the present study, almost all parameters of the CF model were affected by rpCLA supplementation of ewes (Table 4). Supplementation did not affect the potential CF; however, it delayed milk gelation (RCT of 7.0 vs. 9.8 min for control and rpCLA, respectively), slowed CF $\left(\mathrm{k}_{\mathrm{CF}}\right.$ of 49.5 vs. $34.8 \% / \mathrm{min}$, respectively), and doubled the rate of whey expulsion $\left(\mathrm{k}_{\mathrm{SR}}\right.$ of 0.51 to $1.00 \% / \mathrm{min}$, respectively). Furthermore, the incidence of samples that did not show any $\mathrm{CF}$ decrease during the test period was halved in ewes receiving rpCLA supplementation ( $\mathrm{No} \mathrm{k}_{\mathrm{SR}}$ of 30.8 vs. $15.7 \%$, respectively). When we excluded the samples with an apparent lack of syn- eresis, the average values of $\mathrm{k}_{\mathrm{SR}}$ increased to 0.6 and $1.2 \% / \mathrm{min}$, respectively, for control and rpCLA-treated ewes. The effect of rpCLA on the CF curve is shown in Figure 3. The rpCLA-induced changes in the 2 first parameters would be considered negative for cheesemaking, whereas the effect of the change in the third parameter on cheese-making is not yet known.

\section{CONCLUSIONS}

The present study provides new insights into the complex processes of coagulation, $\mathrm{CF}$, and syneresis in ovine milk, and shows that rpCLA supplementation can influence these processes. Despite the phenotypic and genetic diversity of the 3 local sheep breeds tested herein, the ewes produced milk with similar compositions and technological properties. Ovine milk is characterized by a faster gelation after rennet addition, a steeper increase of $\mathrm{CF}$, and a slower decrease of $\mathrm{CF}$ caused by syneresis. These trends are not effectively captured by the single-point analysis of traditional coagulation traits ( $\mathrm{RCT}, \mathrm{k}_{20}$, and $\mathrm{a}_{30}$ ), but the present study showed that they can be fully captured by modeling the entire CF curve over time. This modeling requires the estimation of only 4 parameters, which can be achieved by prolonging the observation time up to 45 min from rennet addition. In sum, we show that rpCLA supplementation of sheep can change the composition and worsen the cheese-making properties of their milk (i.e., by delaying gelation, slowing curd firming, and accelerating syneresis). Future studies are warranted to examine the effects of CLA on cheese yield or quality, assess the relationships with milk coagulation, $\mathrm{CF}$, and syneresis, and identify causal mechanisms.

\section{ACKNOWLEDGMENTS}

The authors thank the Veneto Region (BIONET project) for supporting our sampling and recording activities, the RISIB SMUPR project (no. 4145) for giving us access to the instruments of the NIRS-Food Laboratory, and Alberto Simonetto, Nicola Tormen, Giorgia Stocco, and Cinzia Ribeca of the University of Padova for their cooperation in sample collection, MCP measurements, and initial data analyses. We also thank SILA s.r.l. (Noale, Italy) for providing the rumen-protected CLA used in this trial.

\section{REFERENCES}

AOAC International. 2000. Official Methods of Analysis. 17th ed. AOAC International, Arlington, VA.

Barłowska, J., M. Szwajkowska, Z. Litwińczuk, and J. Król. 2011. Nutritional value and technological suitability of milk from various 
animal species used for dairy production. Compr. Rev. Food Sci. Food Saf. 10:291-302.

Bauman, D. E., J. W. Perfield, K. J. Harvatine, and L. H. Baumgard. 2008. Regulation of fat synthesis by conjugated linoleic acid: Lactation and the ruminant model. J. Nutr. 138:403-409.

Baumgard, L. H., B. A. Corl, D. A. Dwyer, A. Saebo, and D. E. Bauman. 2000. Identification of the conjugated linoleic acid isomer that inhibits milk fat synthesis. Am. J. Physiol. Regul. Integr. Comp. Physiol. 278:R179-R184.

Bencini, R. 2002. Factors affecting the clotting properties of sheep milk. J. Sci. Food Agric. 82:705-719.

Bittante, G. 2011a. Italian animal genetic resources in the domestic animal diversity information system of FAO. Ital. J. Anim. Sci. 10:151-158.

Bittante, G. 2011b. Modeling rennet coagulation time and curd firmness of milk. J. Dairy Sci. 94:5821-5832.

Bittante, G., and A. Cecchinato. 2013. Genetic analysis of the Fouriertransform infrared spectra of bovine milk with emphasis on individual wavelengths related to specific chemical bonds. J. Dairy Sci. 96:5991-6006.

Bittante, G., C. Cipolat-Gotet, and A. Cecchinato. 2013a. Genetic analysis of different measures of cheese-yield and nutrients recovery from individual bovine milk and their genetic relationships with milk yield and composition. J. Dairy Sci. 96:7966-7979.

Bittante, G., B. Contiero, and A. Cecchinato. 2013b. Prolonged observation and modelling of milk coagulation, curd firming, and syneresis. Int. Dairy J. 29:115-123.

Bittante, G., L. Gallo, P. Carnier, M. Cassandro, R. Mantovani, and E. Pastore. 1996. Effects on fertility and litter traits under accelerated lambing scheme in crossbreeding between Finnsheep and an Alpine sheep breed. Small Rumin. Res. 23:43-50.

Bittante, G., M. Penasa, and A. Cecchinato. 2012. Invited review: Genetics and modeling of milk coagulation properties. J. Dairy Sci. 95:6843-6870.

Castañeda-Gutiérrez, E., T. R. Overton, W. R. Butler, and D. E. Bauman. 2005. Dietary supplements of two doses of calcium salts of conjugated linoleic acid during the transition period and early lactation. J. Dairy Sci. 88:1078-1089.

Cecchinato, A. 2013. Survival analysis as a statistical methodology for analyzing factors that affect milk coagulation time in HolsteinFriesian and Brown Swiss cows. J. Dairy Sci. 96:5556-5564.

Cecchinato, A., M. De Marchi, L. Gallo, G. Bittante, and P. Carnier. 2009. Mid-infrared spectroscopy predictions as indicator traits in breeding programs for enhanced coagulation properties of milk. J. Dairy Sci. 92:5304-5313.

Cecchinato, A., M. Penasa, M. De Marchi, L. Gallo, G. Bittante, and P. Carnier. 2011. Genetic parameters of coagulation properties, milk yield, quality, and acidity estimated using coagulating and noncoagulating milk information in Brown Swiss and HolsteinFriesian cows. J. Dairy Sci. 94:4205-4213.

Cipolat-Gotet, C., C. Cecchinato, M. De Marchi, and G. Bittante. 2013. Factors affecting variation of different measures of cheese yield and milk nutrients recovery from individual model cheese manufacturing process. J. Dairy Sci. 96:7952-7965.

Cipolat-Gotet, C., A. Cecchinato, M. De Marchi, M. Penasa, and G. Bittante. 2012. Comparison between mechanical and near-infrared methods for assessing coagulation properties of bovine milk. J. Dairy Sci. 95:6806-6819.

FASS (Federation of Animal Science Societies). 1988. Guide for the Care and Use of Agricultural Animals in Agricultural Research and Teaching. FASS, Champaign, IL.

Dilzer, A., and Y. Park. 2012. Implication of conjugated linoleic acid (CLA) in human health. Crit. Rev. Food Sci. Nutr. 52:488-513.

Gebauer, S. K., J.-M. Chardigny, M. U. Jakobsen, B. Lamarche, A. L. Lock, S. D. Proctor, and D. J. Baer. 2011. Effects of ruminant trans fatty acids on cardiovascular disease and cancer: A comprehensive review of epidemiological, clinical, and mechanistic studies. Adv. Nutr. 2:332-354.

Ghazal, S., V. Berthelot, N. C. Friggens, and P. Schmidely. 2012. Influence of a supplement containing conjugated linoleic acid on dairy performance, milk fatty acid composition, and adipose tissue reac- tivity to lipolytic challenge in mid-lactation goats. J. Dairy Sci. 95:7308-7318.

Gillis, M. H., S. K. Duckett, J. R. Sackmann, C. E. Realini, D. H. Keisler, and T. D. Pringle. 2004. Effects of supplemental rumenprotected conjugated linoleic acid or linoleic acid on feedlot performance, carcass quality, and leptin concentrations in beef cattle. J. Anim. Sci. 82:851-859.

Glasser, F., A. Ferlay, M. Doreau, J. J. Loor, and Y. Chilliard. 2010. $t 10, c 12-18: 2$-induced milk fat depression is less pronounced in cows fed high-concentrate diets. Lipids 45:877-887.

Hötger, K., H. M. Hammon, C. Weber, S. Görs, A. Tröscher, R. M. Bruckmaier, and C. C. Metges. 2013. Supplementation of conjugated linoleic acid in dairy cows reduces endogenous glucose production during early lactation. J. Dairy Sci. 96:2258-2270.

Ikonen, T., K. Ahlfors, R. Kempe, M. Ojala, and O. Ruottinen. 1999. Genetic parameters for the milk coagulation properties and prevalence of noncoagulating milk in Finnish dairy cows. J. Dairy Sci. $82: 205-214$.

Jaramillo, D. P., A. Zamora, B. Guamis, M. Rodrìguez, and A. J. Trujillo. 2008. Cheesemaking aptitude of two Spanish dairy ewe breeds: Changes during lactation and relationship between physico-chemical and technological properties. Small Rumin. Res. 78:48-55

Lock, A. L., M. Rovai, T. A. Gipson, M. J. de Veth, and D. E. Bauman. 2008. A conjugated linoleic acid supplement containing trans-10, cis-12 conjugated linoleic acid reduces milk fat synthesis in lactating goats. J. Dairy Sci. 91:3291-3299.

Maxin, G., F. Glasser, C. Hurtaud, J. L. Peyraud, and H. Rulquin. 2011. Combined effects of trans-10,cis-12 conjugated linoleic acid, propionate, and acetate on milk fat yield and composition in dairy cows. J. Dairy Sci. 94:2051-2059.

McCrorie, T. A., E. M. Keaveney, J. M. W. Wallace, N. Binns, and M. B. E. Livingstone. 2011. Human health effects of conjugated linoleic acid from milk and supplements. Nutr. Res. Rev. 24:206-227.

Mura, M. C., C. Daga, M. Paludo, S. Luridiana, M. Pazzola, S. Bodano, M. L. Dettori, G. M. Vacca, and V. Carcangiu. 2012. Analysis of polymorphism within POU1F1 gene in relation to milk production traits in dairy Sarda sheep breed. Mol. Biol. Rep. 39:6975-6979

NRC. 2007. Nutrient Requirements of Small Ruminants: Sheep, Goats, Cervids, and New World Camelids. Natl. Acad. Press, Washington, DC.

Nuernberg, K., D. Dannenberger, G. Nuernberg, K. Ender, J. Voigt, N. D. Scollan, J. D. Wood, G. R. Nute, and R. I. Richardson. 2005. Effect of a grass-based and a concentrate feeding system on meat quality characteristics and fatty acid composition of longissimus muscle in different cattle breeds. Livest. Prod. Sci. 94:137-147.

Oliveira, D. E., M. A. S. Gama, D. Fernandes, L. O. Tedeschi, and D. E. Bauman. 2012. An unprotected conjugated linoleic acid supplement decreases milk production and secretion of milk components in grazing dairy ewes. J. Dairy Sci. 95:1437-1446.

Park, Y. W., M. Juarez, M. Ramos, and G. F. W. Haenlein. 2007. Physico-chemical characteristics of goat and sheep milk. Small Rumin. Res. 68:88-113.

Pastore, E. 2002. Le razze ovine autoctone del Veneto. Veneto Agricoltura, Legnaro, Padova, Italy.

Pazzola, M., F. Balia, V. Carcangiu, M. L. Dettori, G. Piras, and G. M. Vacca. 2012. Higher somatic cell counted by the electronic counter method do not influence renneting properties of goat milk. Small Rumin. Res. 102:32-36.

Pazzola, M., F. Balia, M. L. Dettori, M. C. Mura, V. Carcangiu, and G. M. Vacca. 2011. Effects of different storage conditions, the farm and the stage of lactation on renneting parameters of goat milk investigated using the Formagraph method. J. Dairy Res. $78: 343-348$.

Pazzola, M., M. L. Dettori, G. Piras, E. Pira, F. Manca, O. Puggioni, A. Noce, and G. M. Vacca. 2013. The effect of long-term freezing on renneting properties of Sarda sheep milk. Agric. Conspec. Sci. $78: 275-279$.

Pellattiero, E., A. Cecchinato, M. De Marchi, M. Penasa, N. Tormen, S. Schiavon, M. Cassandro, and G. Bittante. 2011. Growth rate, 
slaughter traits and meat quality of lambs of three Alpine sheep breeds. Agric. Conspec. Sci. 76:297-300.

Pellegrini, O., F. Remeuf, M. Rivemale, and F. Barillet. 1997. Renneting properties of milk from individual ewes: Influence of genetic and non-genetic variables, and relationship with physicochemical characteristics. J. Dairy Res. 64:355-366.

Ramanzin, M., G. Bittante, and L. Bailoni. 1991. Evaluation of different chromium-mordanted wheat straws for passage rate studies. J. Dairy Sci. 74:2989-2996.

Schiavon, S., and G. Bittante. 2012. Double-muscled and conventional cattle have the same net energy requirements if these are related to mature and current body protein mass, and to gain composition. J. Anim. Sci. 90:3973-3987.

Schiavon, S., M. De Marchi, F. Tagliapietra, L. Bailoni, A. Cecchinato, and G. Bittante. 2011. Effect of high or low protein ration combined or not with rumen protected conjugated linoleic acid (CLA) on meat CLA content and quality traits of double-muscled Piemontese bulls. Meat Sci. 89:133-142

Schiavon, S., F. Tagliapietra, M. Dal Maso, L. Bailoni, and G. Bittante. 2010. Effects of low-protein diets and rumen-protected conjugated linoleic acid on production and carcass traits of growing double-muscled Piemontese bulls. J. Anim. Sci. 88:3372-3383.

Schiavon, S., F. Tagliapietra, F. Dalla, G. Montà, A. Cecchinato, and G. Bittante. 2012. Low protein diets and rumen-protected conjugated linoleic acid increase nitrogen efficiency and reduce the environmental impact of double-muscled young Piemontese bulls. Anim. Feed Sci. Technol. 174:96-107.

Scollan, N., J. F. Hocquette, K. Nuernberg, D. Dannenberger, I. Richardson, and A. Moloney. 2006. Innovations in beef production sys- tems that enhance the nutritional and health value of beef lipids and their relationship with meat quality. Meat Sci. 74:17-33.

Selberg, K. T., A. C. Lowe, C. R. Staples, N. D. Luchini, and L. Badinga. 2004. Production and metabolic responses of periparturient Holstein cows to dietary conjugated linoleic acid and trans-octadecenoic acids. J. Dairy Sci. 87:158-168.

Shingfield, K. J., J. Rouel, and Y. Chilliard. 2009. Effect of calcium salts of a mixture of conjugated linoleic acids containing trans10,cis-12 in the diet on milk fat synthesis in goats. Br. J. Nutr. 101:1006-1019.

Terré, M., A. Nudda, F. Boe, G. Gaias, and A. Bach. 2011. Performance, immune response and fatty acid profile in lambs supplemented with a CLA-mixture. Anim. Feed Sci. Technol. 165:1-7.

Vacca, G. M., M. L. Dettori, F. Balia, S. Luridiana, M. C. Mura, V. Carcangiu, and M. Pazzola. 2013. Sequence polymorphisms at the growth hormone GH1/GH2-N and GH2-Z gene copies and their relationship with dairy traits in domestic sheep (Ovis aries). Mol Biol. Rep. 40:5285-5294.

Van Soest, P. J., J. B. Robertson, and B. A. Lewis. 1991. Methods for dietary fiber, neutral detergent fiber, and nonstarch polysaccharides in relation to animal nutrition. J. Dairy Sci. 74:3583-3597.

Weerasinghe, W. M. P. B., R. G. Wilkinson, A. L. Lock, M. J. de Veth D. E. Bauman, and L. A. Sinclair. 2012. Effect of a supplement containing trans-10, cis-12 conjugated linoleic acid on the performance of dairy ewes fed 2 levels of metabolizable protein and at a restricted energy intake. J. Dairy Sci. 95:109-116.

Woods, V. B., and A. M. Fearon. 2009. Dietary sources of unsaturated fatty acids for animals and their transfer into meat, milk and eggs: A review. Livest. Sci. 126:1-20. 